\title{
Explanation of Potentials and Missing Initiatives in Palestinian Vocational and Technical Education Contents, Structure and Training
}

\author{
Imad S.A.Salem \\ Ph.D. Student, Philosophy and Islamic Civilization, Faculty of Research Institute for Islamic \\ Products and Malay Civilization (INSPIRE), Universiti Sultan Zainal Abidin (UniSZA), \\ Malaysia | Doctor of Philosophy and Islamic Civilization, Bethlehem, Palestine \\ E-mail: i.salem@tvet-pal.org

\section{Dr. Najihah Abd Wahid*} \\ Assoc. Prof, Research Institute for Islamic Products and Malay Civilization (INSPIRE), \\ Universiti Sultan Zainal Abidin (UniSZA), Malaysia | Corresponding Author* \\ E-mail: anajihah@unisza.edu.my
}

\begin{abstract}
The study aims at explaining the missing initiatives in the contents, structure and training of vocational and technical education in Palestine. The impacts of vocational and technical education have not been largely perceived in Palestinian communities as it is yet to be placed on the hierarchy of productivity, growth and development. Apart from a growing number of scholarly responses about the inability of Palestinian vocational and technical education toward meeting market and global needs, it is however important to emphasize that this education is supposed to be a compulsory prerequisite to all students. Hence, with the review of scholarly literature and the application of content analysis through the qualitative method, the paper attempts to explain the potentials and missing initiatives of vocational and technical education in the Palestine context. Arguments were presented in previous literature as regards the importance of vocational and technical education, but none focused on the road to realizing its potentials and identifies the missing initiatives.
\end{abstract}


The study consequently discovered that signs of progress and changes could be realized in the contents, structure and training of vocational and technical education through addressing these missing initiatives.

Keywords: Vocational and Technical Education, Initiatives, Potentials, Contents, Structure, Training

\section{Introduction}

It is fundamental to understand that formal education differs from vocational and technical education. While formal education provides theoretical knowledge to students, vocational and technical education equips students with adequate practical skills to cope with global advancement. Vocational and technical education could prepare students with skills, training, education and knowledge suitable for a variety of jobs (UNESCO, 2015; IGI Global, 2021; INEE, 2021; Ministry of Education, Youth \& Information, 2021; Jens, 2021).

In recent times, it has been so scary for industrialists to employ students who graduated from formal educational settings (universities and colleges). Industrialists' belief on those kinds of students is that their level of attitude, knowledge, experience and skills required by companies and industries will be largely limited, and will be more theoretical than practical. Besides, re-coaching the formal education graduates for the urgently needed industrial task would indeed be of expensive and harmful to industries than benefit. Lately, employers across the world prefer employing vocational and technical graduates to formal education graduates since the speedy delivery of the former is quite faster than the latter (Jens, 2021 \& NACE, 2021). Globalization and hyper-competition have increased the industry's priority toward wanting graduates with technical and creative skills to solve industry issues and control problematic circumstances (Deanna, 2020).

The continuous changes in businesses and industries are increasingly demanding for reformation in the Palestinian formal educational system in the direction of considering and reemphasizing vocational and technical educational structure and contents. Palestinian education curriculum and structure need to be more dynamic in addressing global expectations and modern labour market needs. It should provide a high-quality structure ensuring that vocational and technical skills are adequately delivered to students on a contemporary basis. The structure should be supported by allocating updated resources and providing instructional regulations (OECD, 2021). 
In trying to explain the process of reforming and upgrading Palestinian vocational and technical educational structure, the management is required to collaborate with industries to know the exact attitudes, knowledge and skills expected of them; review programs and modernize occupational standards; provide training opportunities to teachers; ensure quality training and education; and deliver both internal needs and external demands (Anita, 2019; Greatbatch, et. al., 2018; Gisela, et. al., 2018; OECD, 2021). The managers of vocational and technical institutions need to understand the dynamics of vocational and technical concepts; concentrate on acquiring management skills, interpersonal skills, negotiation and marketing skills, creativity and innovation skills, monitoring skills to design institutional objectives and plans; skills to be cognizance with industrial needs; skills to be capable of enhancing the quality of learning, teaching and curriculum; and know-how skills to ensure healthy enabling environments. In other words, it is necessary for the management and providers of vocational and technical education to provide training, environment, education, platforms, knowledge and education responsive and useful at labour market (The World Bank, 2017; Government of Netherlands, 2020). This paper is therefore arguing that understanding the challenges of industries, formal education and vocational and technical education is indicative of meeting the needs and expectations of Palestinian labour markets alongside global targets.

In addition to that, the heavy dependence of gulf countries on expatriates has often been a source of concern. This information may appear reasonable when local businesses and industries are found to be largely controlled by expatriates in the United Arab Emirates (UAE), Kingdom of Saudi Arabia, Oman and Bahrain. Expatriates control major sectors of the economy including infrastructure, eater, oil, electricity and health in these countries. In UAE for instance, almost $90 \%$ of those invariably coordinating these main sectors are expatriates. Ten (10) million out of Saudi Arabia's population are expatriates (Sabena, 2020), thus indicate how poor vocational and technical education has supported locals and indigenes in gulf countries including Palestine. In Kuwait, the empirical report shows that $70 \%$ of the entire population are expatriates from a different continent (World Population Review, 2020). These concerns were further affected by the Covid-19 pandemic which declined jobs at the rate of $13 \%$. As reported by Christopher (2020), 1.2 million ex-pats may likely leave the Kingdom of Saudi Arabia this year. It was similarly forecasted by Christopher (2020) that 30\% of $70 \%$ of ex-pats may probably be reduced because of the outbreak of the Covid-19 pandemic in Kuwait. This indeed indicates that these gulf countries including Palestine fail to promote and support their respective educational structure through vocational and technical training. 
Such attention and intervention may have paved way for an experienced replacement among the indigenes in these countries, most especially, during this hard time of global epidemic. Through a robust plan of vocational and technical education, Palestine and other gulf countries would have made progress and headway in overcoming the existing challenges of limited local manpower to manage and maintain local businesses and industries.

\subsection{Research Objectives}

The focus of this study focuses on explaining the missing initiatives in the contents, structure and training of vocational and technical education in Palestine, working on them and addressing them. The impacts of vocational and technical education are largely realized in Palestinian societies as they have not yet been placed in the hierarchy of productivity, growth and development. Regardless of the growing number of scholarly responses about the inability of Palestinian vocational and technical education to meet the needs of the Palestinian market and global needs, it is important to stress that .such education is supposed to be a prerequisite and mandatory for all students

\subsection{Research Significance}

The study will work by reviewing the scientific literature and applying content analysis to explain the missing potentials and initiatives for vocational and technical education in the Palestinian context. Focusing on the importance of vocational and technical education, as well as on the ways in which the potential of vocational and technical education in Palestine will be achieved, and identifying missing initiatives. Thus, showing signs of progress and changes that can be achieved in the contents, structure and training of TVET while at the same time addressing these lost initiatives.

\section{Challenges in Palestinian Vocational And Technical Educational System}

There is a widespread agreement that coherence has been an absent mechanism in the structural composition of many vocational and technical education systems. Hiim (2017) argued that distance between practice and theory and inconsistency between workplace needs and educational graduates denied VTE from producing salutary results, most especially, in Palestine communities. Hiim (2016) contended that vocational and technical training is mostly considered irrelevant alongside recognized professions at formal institutions. Dahlback et al (2018) observed that there is disunity, conflict and inconsistency between the education offered at formal schools and skills needed at workplaces. 
Education and teaching have been quite broad in focus, but lacks the essential contents needed and expected in industries (Dahlback et al., 2018). These challenges remain global and have no exceptional consideration for Palestine.

According to Sylte (2018), assessment methods and teaching contents in the formal educational structure inclined more on theory than practical, thus render formal institution graduates irrelevant in industries and workplaces. It has become a source of concern as to whether the contents in the Palestinian formal educational system largely represent the demands in its labour market. It is not difficult to conclude that Palestine needs industrial and labour market experts, but can the existing design and structure produce that? Hence, the main goal of the study is to explain the missing initiatives in the contents, structure and training of vocational and technical education in Palestine.

The formal educational system mostly emphasized creating scientific and analytical thinkers rather than complex practical work solvers. Billett (2010) asserted that work demands and technological advancements call for unlimited learning exercises. Continuous societal changes proclaim for diversifying the importance and functions of vocational and technical education. Hiim (2016) corroborated the fact that VTE would significantly and appreciably promote workplace performances.

As indicated and established by Guile \& Unwin (2019a), the effectiveness of vocational and technical education is increasingly staggering in many nations, as their roles and functions have been lately difficult to be perceived and identified. VTE may drastically lose relevance and become ineffective if its programs are not merged with work-life changes. Work-life is growingly transforming and advancing beyond most existing formal institutional contents, structure, curriculum, focus and setting. Apart from VTE training, the contemporary educational setting is expected to concentrate on producing students possessing innovative skills, creative skills, problemsolving skills, critical thinking skills, developmental skills and managerial skills beyond academic scholars and experts (Sylte, 2020).

\section{Features and Characteristics of Vocational and Technical Learner}

By meaningfully and realistically building a vocational and technical learner, several criteria need to be systematically demonstrated. Some fulfilled criteria and possessed features in the learner would indeed affirm it that major sectors in the economy will no longer be vacant or largely occupied by expatriates alongside the building of VTE learners. 
The learner's level of participation in economic, growth, management, investment and policy decisions need to be more professional, constructive and worthwhile after receiving vocational and technical training. Following such an educational journey, the learner is expected to be a human resource in exploring and discovering new opportunities for the country. The learner would not be viewed from a valuable perspective if the performance does not correspond with the labour market needs.

The graduation of the vocational and technical learner must certainly be seen and perceived in institutional, industrial, regional and national development processes. The learner's mindset, orientation, ideas and initiatives need to be more creative than being a critic or enemy of progress. It would be embarrassing for a vocational and technical learner to lack knowledge, skills and experiences needed at the workplace which falls under the learner's area of expertise (Bisht \& Pattanaik, 2020). The person should be able to identify lucrative initiatives for the industry. The learner should possess the ability to think both theoretically and practically toward discharging work assignments and solving the company's problems. It would be embarrassing for such a learner to lack knowledge and understanding of acting intuitively to workplace concerns.

The justification of "how" and "why" in workplaces should be professionally understood by the learner. All subjects related to a workplace should be practically and theoretically comprehended at an appreciable level because workplace demands require professional approaches.

\section{Management Responsibilities in Realizing the Potentials of Vocational and Technical Education}

It is important and appropriate to constitute a competent management team that can collaborate with local businesses and industries. Simone (2020) submitted that the potential effect of such collaboration between local industries and vocational and technical institutions is that the unemployment rate will drastically decline. A significant responsibility that can feature and expose the effectiveness and productivity of the management is the ability to design and point out the required attitudes, skills, experience and knowledge expected of vocational and technical graduates. It would be a plausible honour for the management to ensure that indigenous manpower replaces foreign expatriates and occupies major and essential sectors of the Palestinian economy in a short time. 
The indispensable role of the management is to frequently engage with the labour market on their urgent needs and link vocational and technical education (VTE) management's programs with societal wants and challenges.

Palestinian government should not just focus on preparing individuals and students per international requirements, but also address the imbalances between local industries and vocational and technical education. The economic and social development of the nation must be stressed upon by VTE management. The issue of reducing the heavy dependence of the nation on expatriates should particularly be listed on the priority list. Several measures must be put in place by the management toward responding to business needs and industrial requirements. It is highly recommended that the management ensures that curriculum, policies, strategies and learning processes represent industrial wants and expectations (Ministry of Education and Sports, 2019; OECD, 2021). Most importantly, the management should set the action plan, create the database, review and develop curriculum following the international standard, often conduct workshops and training, design prerequisites for assessing students, conduct collaborative research, analyze the market and industrial requirements, and determine the level of required knowledge, attitudes and skills. The management needs to make constant and necessary reforms towards ensuring quality design, programs and policies. This effort will definitely result in creating and increasing job opportunities and skilled manpower to cater for national and regional labor market demands.

In the process of strengthening the effectiveness of vocational and technical education, VTE management should consider following the below process. 


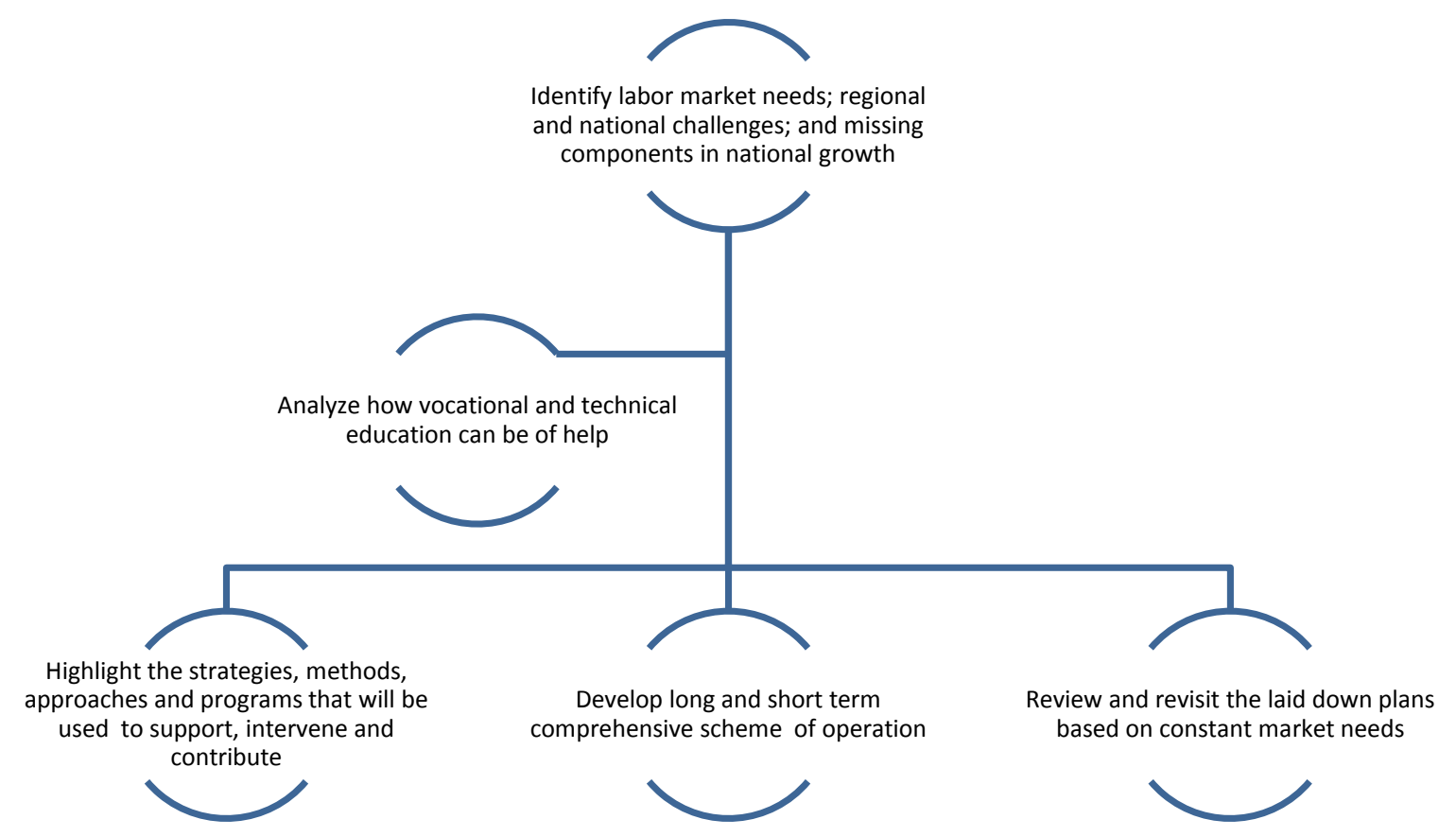

\section{Diagram 1: Responsibility of the management of vocational and technical education}

Toward hoping for a desirable objective, it would be a progressive idea for the management to consider cultural and socioeconomic factors (Pilz et al., 2020). This is because importing foreign frameworks and policies may not end well in the Palestinian context due to several cultural, national and socioeconomic factors. They should be able to distinguish culturally acceptable tactics from culturally unacceptable approaches in the course of developing a standardized framework for Palestinians. Professions and areas of expertise are supposed to be developed by VTE management following labour market demands.

Management should be capable of identifying and diagnosing situational factors as they will assist in designing and enhancing vocational and technical educational structures (Andela \& van der Doef, 2018). Toward facilitating training exercises for the learners, social support is essential. The capacity and environment for building self-esteem, developing competency and satisfying future careers should be provided by the management of vocational and technical education.

The management and trainers of vocational and technical education need to understand how their roles and interventions could influence major sectors in the economy, national growth and unemployment rate across the country. 
They must be cognizant and familiar with special needs suitable for the development of vocational and technical training departments and sectors in Palestine. It would be unprofessional and amateurish for them to neglect or reduce their fundamental responsibilities for these trainers merely because of personal and political interests, as this training exercise does not solely prepare them for the company, but also the future. Measuring daily structural programs with global market needs would suitably and adequately prepare vocational and technical trainers for any labour market. The management is required to design programs that will allow VTE trainers to solve complex problems related to their respective areas of expertise. VTE educational system should consider focusing on occupational programs that address unemployment challenges. The management should ensure that the programs are open for innovation, changes and advancement, and are also job-related in content and focus. They should endeavour to ensure that culture doesn't be a challenge to make modifications, adjustments and expansions in vocational and technical education programs.

\section{The Missing Initiatives in Palestinian Vocational and Technical Sectors}

Toward ensuring that the vocational and technical education sector effectively responds and addresses transformational, sustainable and economic challenges in the $21^{\text {st }}$ century, standardized transformations are needed in the context of governing, funding, organizing and conceptualizing its educational system (Bang \& Park, 2021). Palestinian government needs to develop friendly policies to match VTE training schemes with industrial demands. The marginalized groups; villagers, vulnerable and unemployed workers; low-skilled adults and disadvantaged communities should be given a crucial portion and unlimited attention in the transformational process.

Beyond depending on expatriates, providers and management of vocational and technical education need to review their programs from the perspective of ensuring that the absence of expatriates would not be a major disaster to major sectors of the Palestinian economy. The providers should not exclude education, transportation, agriculture, public health, human resource development and green growth infrastructure while expanding and diversifying VTE programs in the Palestine context. Factors like sustainability, efficiency and relevancy of these programs should also be a fundamental concern for the providers. The mechanisms for increasing employment rate, and strengthening infrastructures and capacity building must be emphasized and prioritized in the process.

In a search for the missing initiative in VTE structure, it is important to review the formal and informal educational curriculum to identify the gaps that could be filled by VTE programs. 
The current challenges of VTE programs must be identified by the government, management, providers and policymakers before exploring solutions. In other words, it would be a misplacement of steps if solutions were provided before knowing the problems. Hence, the missing initiatives could be addressed through revisiting experiences; training, training curriculum, training courses and retraining schemes; educational contents, methods and approaches; investment in skills, capacity building and human resources; objectives, purpose, mission and visions of establishing VT education in Palestine.

\section{Conclusion}

The aforementioned initiatives are missing in Palestinian strategic-goals toward VTE sectors. Discipline-based educational systems and structures are contemporarily irrelevant in the $21^{\text {st }}$ century. Palestinian educational planners need to collaborate with VTE management toward constructing curriculum and considering changes in the future workplace. Industry practical knowledge should be given priority in students' educational structure. The unemployment rate across Palestine demonstrate the need for using industrial tasks, challenges and changes to link practical knowledge to theoretical knowledge, and build comprehensive educational programs. Practical experiences and knowledge would indeed help in promoting relevance at workplaces. Theoretical teaching methods won't squarely discharge industry tasks and would lack the technic of solving workplace challenges.

Changes in industry and workplace could easily be addressed in VTE educational structure rather than in the formal educational setting. The inability of knowledge-based curricula to meet industrial needs in Palestine gives an avenue for VTE programs to be expanded, supported and planned alongside labour market demands. Job-relevant teaching methods are meaningful ways that could help in reducing the level of unemployment in Palestine.

The great responsibility of causing any changes to vocational and technical structured programs lies with the management. It would be unprofessional and substandard for the management to reform VTE programs without considering work-based learning methods, context-based learning approaches and job-relevant theories.

It is fundamental for educational planners to understand that workplaces are increasingly demanding for qualities beyond the existing educational programs. Therefore, the objective of vocational and technical education should not be merely limited to preparing students for workplaces and industries, but should be an extensive initiative for addressing social, educational and economic goals. 
By acknowledging the uniqueness of VTE, the Palestinian government can create many experts in various progressive and developmental sectors. By extending the programs through the lens of industrial demands, the ratio of labour participation would increase substantially. On that account, it would be discerning to address the aforementioned initiatives for progression.

\section{References}

Andela, M., \& van der Doef, M. (2018). A comprehensive assessment of the person - Environment fit dimensions and their relationships with work-related outcomes. Journal of Career Development, 46(5), 567-582. https://doi.org/10.1177/0894845318789512

Anita Lice, (2019), "Managing vocational education to facilitate the employability of graduates", Human, technological and quality of Education, 2019.

Bang Yonghwan \& Park Taejung. (2021). Needs Analysis in Technical Vocational Education and Training (TVET) Programs for Sustainable Development of Women in Cambodian Hair and Beauty Industry. Journal of Technical Education and Training Vol. 13 No. 3 (2021) p. 115124.

Billett, S. (2010). Learning through practice. In S. Billett (Ed.), Learning through practice: Models, tra $\neg$ ditions, orientations and approaches (pp. 1-20). Springer.

Bisht, N., \& Pattanaik, F. (2020). Exploring the magnitude of inclusion of Indian youth in the world of work based on choices of educational attainment. Journal of Economics and Development, 23(2), 128-143. http://doi.org/10.1108/JED-08-2020-0114

Christopher Copper, (2020), "1.2 million expats forecast to leave Saudi Arabia this year", 19 June 2020, International Investment. https://worldpopulationreview.com/countries/kuwaitpopulation

Dahlback, J., Olstad, H. B., Sylte, A. L., \& Wolden, A. C. (2018). Utfordringer og muligheter i møte $\neg$ punktet mellom yrkesfaglærerutdanningen og pedagogisk praksis i videregående skole [Chal $\neg$ lenges and opportunities in the meeting point between vocational teacher education and pedᄀagogical practice]. Nordic Journal of Vocational Education and Training, 8(3). 5777. https://doi. org/10.3384/njvet.2242-458X.188357 
Deanna Pate, (2020), “The top skills companies need most in 2020-and how to learn them”, Learning Blog, 2020.

Gisela Wiesner, Nurhening Yuniarti, (2017), "Systematic quality management vocationaleducation insttitues: role of teachers in development of organization quality", Journal Pendidkian Teknologi Dan Kejuruan, Vol. 24, No.1, May 2018, pp.162-170.

Government of Netherlands, (2020), "Closing the gap between education and industry", 2020. https://www.government.nl/topics/enterprise-and-innovation/closing-the-gap-betweeneducation-and-industry

Greatbatch, D. and S. Tate (2018), “Teaching, leadership and governance in FE colleges”, Research Report,

https://assets.publishing.service.gov.uk/government/uploads/system/uploads/attachment_data /file/680306/Teaching_leadership_and_governance_in_Further_Education.pdf

Guile, D., \& Unwin, L. (2019a). Introduction to the handbook: Vocational Education and Training (VET) theory, practice and policy for a complex field of inquiry. In D. Guile \& L. Unwin (Eds.), The Wiley Handbook of Vocational Education and Training (pp. 1-39). John Wiley \& Sons.

Guile, D., \& Unwin, L. (2019b). VET, expertise and work: situating the challenge for the twenty-first century. In D. Guile \& L. Unwin (Eds.), The Wiley Handbook of Vocational Education and Training (pp. 19-40). John Wiley \& Sons.

Hiim, H. (2016). Educational action research and the development of professional teacher knowledge. In E. Gunnarsson, H. P. Hansen, B. S. Nielsen \& N. Sriskandarajah (Eds.), Action research for demo $c$ cracy: New ideas and perspectives from Scandinavia (pp. 147161). Routledge.

Hiim, H. (2016). Educational action research and the development of professional teacher knowledge. In E. Gunnarsson, H. P. Hansen, B. S. Nielsen \& N. Sriskandarajah (Eds.), Action research for demo $c$ cracy: New ideas and perspectives from Scandinavia (pp. 147161). Routledge.

Hiim, H. (2017). Ensuring curriculum relevance in vocational education and training: Epistemolongical perspectives in a curriculum research project aimed at improving the 
relevance of the Nor $\neg$ wegian VET. International Journal for Research in Vocational Education and Training, 4(1), 1-19. https://doi.org/10.13152/IJRVET.4.1.1

IGI Global, (2021), "What is technical and vocational education and training, TVET", IGI Global, Published of Timely Knowledge, 2021.

Inter-agency Network for Education in Emergencies, (2021), “Technical and vocational education and training, TVET”, INEE, 2021.

Jens-Henning Peters, (2021), “The importance of vocational training for career development”, EHL Insights Group, Switzerland, 2021.

Ministry of Education and Sports, (2019), "The Technical Vocational Education and Training (TVET) Policy”. Republic of Uganda. 2020.

Ministry of Education, Youth \& Information, (2021), “Technical and Vocational Unit”, Government of Jamaica, 2021.

National Association of Colleges and Employers, (2021), “What is career readiness?”, NACE, 2021.

OECD, (2021), “OECD reviews of vocational education and training” OECD Library, 2021.

OECD, (2021), “Teachers and leaders in vocational education and training”, OECD Reviews of Vocational Educational and Training, 2021.

Pilz, M., Harris, R., Zenner-Höffkes, L., \& Zirkle, C. (2020). Undertaking comparative VET research in international teams: The example of exploring recruitment and training cultures in SMEs in Australia Germany and the United States. In M. Pilz \& J. Li (Eds.), Comparative vocational educa $\neg$ tion research: Enduring challenges and new ways forward (pp. 291-309). Springer VS. https://doi. org/10.1007/978-3-658-29924-8_17

Sabena Siddiqui, (2020), "GCC faces possible setback with exodus of skilled professionals”, AlMonitor, June 22, 2020. https://www.al-monitor.com/originals/2020/06/gulf-state-gccexodus-saudi-arabia-wokers-uae-kuwait.html

Simone R. Haasler, (2020), “The German System of Vocational Education and Training: Challenge of gender, Academization and the Integration of Low-Achieving Youth", Transfer: European review of Labour and Research, February 12, 2020. https://doi.org/10.1177/1024258919898115 
Academic Journal of Research and Scientific Publishing | Vol 3 | Issue 31

Publication Date: 5-11-2021

Sylte, A. L. (2018). Profesjonsretting og studentaktivitet [Professionalisation and student activity]. Scandinavian Journal of Vocations in Development, 3, 1-26. https://dx.doi.org/10.7577/sjvd.2694

Sylte, A. L. (2020). Predicting the Future Competence Needs in Working Life: Didactical Implications for VET in Norway. International Journal for Research in Vocational Education and Training (IJRVET) 2020, Vol. 7, Issue 2, 167-192 https://doi.org/10.13152/IJRVET.7.2.3

The World Bank (2017), “Improving Vocational Education Brings Opportunities for Young People in Yannan", March 13, 2017.

UNESCO. (2015), “TVETpedia Glossary”, UNESCO, International Centre for Technical and Vocational Education and Training, 2015.

World Population Review, (2020), Worldometer, 2020. https://www.worldometers.info/worldpopulation/kuwait-population/

Copyright (C) 2021 Imad S.A.Salem, Dr. Najihah A.W, AJRSP. This is an Open-Access Article Distributed under the Terms of the Creative Commons Attribution License (CC BY NC) Doi: doi.org/10.52132/Ajrsp.e.2021.31.2 